\title{
Research on the Application of Students Self-management in Chinese Universities
}

\author{
Sun Cui \\ School of Economy and Management \\ Shenyang Aerospace University \\ Shenyang City, China
}

\begin{abstract}
Students self-management takes up an important position in universities management. It influences the main part and progress of the management of universities. The goal of modern education management is to promote the all-round development of students, thus improve their comprehensive quality. The current self-management of university students has become the focus of the whole society. This requires the university's internal management staff to do further study about it. With the continuous expansion of the colleges and universities scale, teaching concept has been updated as well. In addition, the internal management model diversifies increasingly in which students' self-management is indispensable. It is an effective way to cultivate students' self-discipline and independent ability. Under the current management system, the internal takes students self-management as the core to monitor the whole school management and encourages students' self-education, self-management and self-service to improve independent ability and responsibility consciousness of contemporary university student, thus to ensure the scientific rationality of management activities. However, in terms of the current management for universities students, problems more or less exist. Most leadership ideas are conservative and attention paid to students' self-management is not enough. It's a lack of perfect management system and professional management talents .Considering the university students are a special group, it's an urgent task need to carry on an education reform for students' self-management. This paper analyzes the existing problems in students' self-management, put forward the corresponding solution measures and summarizes the significance of students' self- management.
\end{abstract}

Keywords-University management; Students selfmanagement; Solutions

After joining the WTO, thanks to the factors such as rapid development of China's economy and education reform in the new situation, the education development of universities springs up. As a result, China's institutions of colleges and universities should consider how to reform to adapt to the era of the current development needs. In addition to strict internal management, the students' self-management is also necessary to be promoted. By means of allowing students to manage themselves, it makes them adapt to the environment in universities more quickly, improve the comprehensive quality of the students effectively and lay the foundation for students to step into society.
Furthermore, it can stabilize the management system of the universities to a certain extent, and improve the management efficiency thus make the daily management work tend to more scientific and reasonable. Statistics show that the improvement of students' self-management in our universities still has a long way to go. It has different depth problems in different levels.From the microscopic point of view, it affects the sustainable development of the students. From the macroscopic, it affects the development process of the modern education management reform in universities.

\section{THE SIGNIFICANCE OF STUDENTS'SELF- MANAGEMENT}

\section{A. To enhance the competitiveness of universities}

Students' self- management refers to in the teaching management of the universities, allowing students to manage themselves to achieve the final goal of the universities. It not only saves the faculty and management cost but also improves the competitiveness of the universities. Our country discussed the management mode of the universities long ago and put forward the implementation measures of students' self-management with the purpose of improving the competitiveness of the universities and cultivating excellent talents for the country. Students' self-management mode which is a vital part of modern university management should combine with the current teaching management concept and ensure its validity to avoid being the superficies.

\section{B. Inevitable choice of university development}

Management reform in China's universities has been advocated all the time. It not only accords with the requirement of modern education reform but also conforms to the current trends of the development of the era. In recent years, the teaching mode has been changed in China's universities. With the increasing enrollment, higher education has been largely converted to mass education. Therefore, at present it's an inevitable choice for development of universities to carry on students' self-management. Find the management method suitable for universities to achieve the optimization of resource allocation by innovating of traditional management mode. 


\section{Enhance the management level of universities}

In recent years, with the great attention paid to the national education and education fund invested by our country, the education mode of universities has been accepted by most enterprises. Besides, the graduates are more and more in society with time goes by. However, it's not so optimistic from the social feedback. Most of the graduates have weak practice ability, even lacking of basic work ability. Some university students have low comprehensive quality, lack of responsibility and often just focus on their own interests. The purpose of university education is to provide comprehensive talents to the society. As a result, it's a primary job for universities to deepen the reform of current management mode and improve the related management mode. It's also an effective way to promote the management in universities.

\section{Improve independent ability of the university students}

With the change of the education system in universities, universities no longer arrange jobs for graduates, but ask them to choose their own career. It's optimistic that the demand for talent in society doesn't reduce. But the enterprises optimized the selection methods of talents. The students need to enrich their professional knowledge and improve their ability according to the demand of the society. The consequence of this change is both good and bad for students. The choices are in their own hands and they are never as lazy as before. Thus it's helpful for students to self-discipline, adapt to the university environment as soon as possible, and improve their comprehensive quality to lay a good foundation for stepping into society in the future. On the contrary, if the students don't carry on their management constraints, there will be the opposite case and affect the future development.

\section{PROBLEMS EXISTING IN STUDENTS SELF-MANAGEMENT}

\section{A. Students don't have high requirement for their own}

There are mainly two parts for students' self-management system in current university, namely the students' self-management and students being involved in school management. The result is not good. The reason is that the students don't have high requirements for their owe both in daily life and in learning respect. They can never take good care for themselves. Some students can't do their own laundry or put away stuff. They lack of the basic common sense, especially the boys. Some students involve in school management with certain purposes. If it's not related to their own interests when they participate in some activities, they think it's a waste of time even refuse to show up.

\section{B. Personnel in charge of the students' self-management don't value the job}

In universities, the students' self-management system is not perfect enough and many people don't know enough for its theory, especially some of the school leaders. Standardized system is hard to establish. It's common to handle problems with experience in management, inevitably there are some problems and there is no rule to follow. Another outstanding problem is that not follow the rule. That is to say, the students' self-management which is just superficial in universities only makes a pose during leadership inspection and can't really work. Besides the leaders, many staff in charge of the self-management doesn't have enough understanding. They only have some literal meaning and in later management, they will become a mere formality. Or the staff doesn't work seriously and they are slack in work .These will lead to a weak level of the students' self-management in universities and damage the development of students. Some university management personnel with low overall quality have no or poor faith. The ability to deal with affairs varies greatly. In students' management work, they can't effectively guide students. They don't want contributions but beg for no fault. They have no accomplishment and lack of basic creativeness and initiative.

\section{Students'self-management system not perfect}

Despite from some universities for students' self-management or the environment, fund and manpower hinder the establishment of students' self-management. The basis of the students' selfmanagement will still be weak even after the establishment. In this case, it only makes it superficial and it's hard to ensure its scientific rationality. Also, the teaching concept of the teachers which is relatively backward is still in the past management patterns, and doesn't adjust the internal management structure in time. In addition, they still use the traditional management mode to restrain both teachers and students not people-oriented. It not only discourages the teachers and students but is unfavorable to the students' self-management work.

\section{Unreasonable arrangement of the university management task}

Our teaching organization and management often use hierarchy, in which only the leadership has decision-making right. Besides, the development of the era is based on economic interests and social pressure also impedes the establishment of students' self-management in universities. First of all, the self-discipline of students is so bad that they can't manage independently well. In particular, some students haven't formed independent thinking under the traditional education management mode for years, thus unable to effectively achieve self- management. Second, most of the contemporary university students are the only child in the family and being spoiled by parents, so they can't recognizer or discipline themselves well.

\section{COUNTERMEASURE ANALYSIS OF THE UNIVERSITY STUDENTS' SELF-MANAGEMENT UNDER THE NEW SITUATION}

\section{A. Enhance the students' ability of independence}

First of all, students should formulate perfect their own management methods to improve their own ability of constraint control and achieve the goal of 
self-management. In daily life, they need to discipline themselves strictly. Don't smoke, drink or get to the internet all through the night. Try to do their own things by themselves and cultivate elegant life interest. As the saying goes, the body is the capital pf revolution. Contemporary university students need a good timetable and do exercise actively. Secondly, students should improve their comprehensive quality and be honest when getting along with others. When doing other things, don't get anxious to achieve quick success and get instant benefits. Lastly, students should get into the habit of independent and enhance their own self-management.

\section{B. Enhance the responsibility consciousness of the management personnel}

By improving the responsibility consciousness of the university management staff and person in charge can we carry on the students' self-management work fundamentally and make university students management independently perform more thoroughly. Firstly, the management staff should fully realize the importance of students' self-management and study the related advanced management concept. Secondly, according to the university internal conditions, formulate students' management system and constantly improve it in the development process. Lastly, it's also indispensable to conduct propaganda to the entire school student and educate them on a regular basis. This will from the atmosphere of universities, and good for cultivating students' independent ability. What's more, enhancing the professional quality of the internal management personnel is also needed. Study the problems frequently appear in students' self-management to minimize mistakes at work. Next it is about the education referring to professional ethics. The relevant personnel shall comply with the national law system and eradicate completely the occurrence of corruption. Last but not least, universities can separate unrelated duties and establish rewards and punishment system and so on.

\section{Improve teaching management system}

Students' self-management includes management system, propaganda and management result analysis and so on. The establishment and improvement needs to restrict and supplement each other between the internal departments. Under this premise, they establish management tasks and divide responsibilities and enable all management information release fasted. Management personnel of the university need to be realistic, change the old management mode, implement the people-oriented idea in management and let go the management of students to ask students gradually learn self-management and strengthen their comprehensive ability. At the same time, it also requires to strengthen the construction of campus culture and promote the vigorous development of universities.

\section{Rational students self-management arrangements}

With the continuous change of the teaching management mode in universities, it requires rational students self-management if the school side wants a stable development. To begin with, the university management staff should realize the significance of students self-management to students even to the university. Give them enough space and let them learn self-management and self-reliance. Secondly, the teaching staff should investigate deep in school to know the real condition of students, arrange more lectures on students self-management and guide them to carry on diversified development. In addition, the university should hold more activities, such as sports meeting to build the platform for students further growth. It is more beneficial for students to carry on self-management and enhance self-discipline and competitiveness.

\section{CONCLUSION}

Under the situation of international and domestic education reform, it's urgent to carry on the reform to university management. By students self-management, it enhances the capability of self-management to ensure the scientific rationality of administrative activities of universities. We shall do our duty work well according to our own problem inside the university, change the existing management idea, establish the relatively perfect students self-management system and implement this job fundamentally. Hereby, it enhances the independent ability and responsibility consciousness of the contemporary university students and ensures the steady management of universities thus promote the vigorous development of our national education career,

\section{REFERENCES}

[1] Li Rui. Key to Success for $21^{\text {st }}$ Century College Students-Self-management [J]. Gansu Journal, 2005.5

[2] Jiang Ruifang.On Contemporary University Students' "Self-education, Self-management and Self-service." [J].Journal of Fujian Medical University. 2002.3

[3] Luo Hong. People-orientated, Value Cultivating the Ability of University Students "Self-education and Self-management" [J].Journal of Shanxi Medical University, 2003.5

[4] [US.]John·S·Brubeck. Selected Tanslation by Chengxu, Zheng Jiwei, Zhang Weiping, Xu Hui, Zhang Min. Higher Education Philosophy [M].Hangzhou: Zhejiang Education Publisher, 2004

[5] [US.] Derek·Bok. Translated by Xu Xiaozhou\&Chen Jun. Walk out of the Ivory Tower-Social Responsibility of Modern University [M].Hangzhou: Zhejiang Education Publisher, 2001

[6]Lao Kaisheng(chief editor) .Introduction to Higher Education Law[M]. Beijing Normal University Publisher, 1999

[7] Lao Kaisheng, Zheng Xinrong .etc. Norms and Standards-Education Management and Law [M]. Beijing Railway Publisher, 1997

[8]Qin Huimin.Concept Collision and Rights Conflict in the Legal Trend of University Management-Thinking Caused by Present Case [J].Journal of Modern University Education2002

[9]Qin Huimin. Challenges Facing University Management in the Process of Our Legal System [J].Journal of Tsinghua University Education research. 2001(2)

[10]Bai Lei, Li Zuxiang. Concept and Strategy of University Students "Learning Freedom" [J]. Journal of Inner Mongolia Science \& Technology and Economy. 2004(1)

[11]Zhao Fuhua. Starting Point and End of the University Students Management [J]. Journal of Tianjin Institute of Finance and Trade Management Cadre.2004(1)

[12]Zhao Zhenjie. Further Discussion of the Students Behavior Management-from the Respect of Habit Development and Self-management [J] Journal of Nanyang Normal University (Social science edition).2004(4) 